Mit dieser Reaktion ist es mir möglich, die behandelten Luetiker fortwährend in ihrer Besserung durch die eingeleitete Therapie zahlenmäßig zu kontrollieren und außerdem ungefähr $25 \%$ mehr positive Reaktionen bei ihnen (über alle Stadien berechnet) zu erzielen als mit der originellen Reaktion. Nicht syphilitische Patienten fand ich nie positiv.

Daß wirklich die Paradoxie der Sera durch meine Methodik aufgehoben wird, habe ich auf S. $253 \mathrm{ff}$. des genannten Artikels schon angedeutet. Jetzt kann ich noch hinzufügen, daß, wenn verschiedene Untersucher dasselbe Serum mit verschiedenen (guten) Extrakten, Ambozeptoren und Komplementen quantitativ nach meinen Angaben prüfen und nicht denselben syphilitischen Index finden, von einem oder mehreren oder allen ein technischer Fehler gemacht worden ist.

Daher auch ist der Name und die Bezeichnung ,.Syphilitischer Index" $(\Sigma . I)$ richtig. Größere Differenzen als 0,1 zwischen den Indices im selben Serum, von verschiedenen Untersuchern gefunden, müssen auf einem Fehler beruhen.

Dr. Rudolf Massini schreibt auf S. 1311 der Münchener medizinischen Wochenschrift (Nr. 24) dieses Jahres: „Außer der mangelnden Spezifizität und Konstanz hat die Wa.R. noch einen anderen großen Fehler, sie hat keine absoluten Werte für den Grad der Hemmung." Ich erwidere, daß 1. die Spezifizität größer ist, als Massini denkt, 2. die Konstanz nahezu absolut ist, 3. die Wa.R. meiner Meinung nach wohl absoluten Wert für den Grad der Hemmung hat, weon nach meinen Angaben das Komplement in einem wirklichen Vorversuch genau austitriert wird.

Amsterdam, 14. August 1912.

Aus dem Laboratorium des Onze Lieve Vrouwe Gasthuis in Amsterdam.

\section{Die Bedeutung der paradoxen Sera bei der Wa.R.}

\section{Von Dr. B. P. Sormani.}

Dr. M e ir ow sk y hat in Nr. 27 dieser Wochenschrift die Bedeutung der „paradoxen Sera" beschrieben. Infolge einer Reise war es mir unmöglich, eher auf seine Behauptungen zu antworten.

Wie es scheint, ist ihm mein Artikel in der Zeitschrift für Immunitätsforschung ${ }^{2}$ ) unbekannt geblieben, denn darin sprach ich als gut begründetc Verniutung aus, daß, wenn nach meinen Angaben gearbeitet wird, paradoxe Sera nicht gefunden werden würden. Jetzt, nachdem ich seit dieser Veröffentlichung wieder mehr als 1000 Sera wiederholt untersucht habe, kann ich mit Sicherheit behaupten, daß paradoxe Sera einfach nicht bestehen.

Der hauptsächlichste Unterschied meiner Methodik mit der der originellen Reaktion liegt in der Behandlung der Blutkörperchen und in der Art, wie man den Vorversuch anstellt.

Man wäscht die Blutkörperchen, bis die abzentrifugierte Kochsalzlösung kein Eiweiß (Kochprobe) mehr enthält. Dann wird die gleiche Quantität einer Ambozeptorverdünnung zugefügt, die 10-15 Einheiten stark ist; das Gemisch wird zwei Stunden in den Schrank gestellt, dann zentrifugiert, noch einmal gewaschen, und die so behandelten Blutkörperchen mit soviel Kochsalzlösung aufgeschwemmt, bis wieder diesclbe Menge der Mischung erreicht ist. Dann wird der Vorversuch auf die angegebene Weise angestellt, und die damit gefundenen Komplementquanten im Hauptversuch benutzt.

Es ist dann ganz gleichgültig:

1. welches alkoholische Lueslebersekret man benutzt, vorausgesetzt, es sei nicht hämolytisch und von bekannter guter Wirksamkeit ${ }^{3}$;

2. wie stark (innerhalb gewisser Grenzen) die stärkste der fün Extraktverdünnungen ist, wenn nur die schwächste etwa $1 \%$ ig genommen wird und die Konzentrationsdifferenz zwischen den aufeinanderfolgenden Verdünnungen ein Viertel derselben zwischen der stärksten und schwächsten ist. Zun Beispiel, man findet im selben Serum denselben Index, wenn von einem Extrakte benutzt wird 0,25 - 0,19 - 0,13 $-0,07-0,01$ oder $0,17-0,13-0,09-0,05 \ldots 0,01$. Nur müssen für 0,25 und 0,17 die benötigten Komplementmengen in zwei Vorversuchen gemessen werden.

3. Es ist ferner gleichgültig, wie viel Ambozeptoren die untersuchten Sera enthalten; denn die abzentrifugierte Flüssigkeit nach dem Sensibilisieren enthält noch viel Ambozeptor, und die Blutkörperchen können also (praktisch geredet) nicht mehr aufnehmen;

4. ferner, wie stark die Blutemulsion (3-, 5- oder $10 \%$ ig),

5. welches Komplement (frisch) man benutzt und wie stark es wirkt.

Im Vorversuch namentlich werden alle zu benutzenden Faktoren sozusagen einander gegenüber ausbalanciert, und man bekommt absolut unveränderliche Resultate im Hauptversuch, vorausgesetzt, daß die schwierige Technik tadellos ausgeführt wird.

1) Verhandlungen der Deutsehen Gesellsehaft für Chirurgie 1911.

2) Orig.-Bd. 11, H. 2, 1911. ${ }^{3}$ ) l. c. S. 260 